\title{
GEFT protein expression in digestive tract malignant tumors and its clinical significance
}

\author{
YUANYUAN WANG, BING ZHANG, GE GAO, YINPING ZHANG and QINGXIN XIA \\ Department of Pathology, The Affiliated Cancer Hospital of Zhengzhou University, \\ Henan Cancer Hospital, Zhengzhou, Henan 450008, P.R. China
}

Received March 8, 2019; Accepted August 13, 2019

DOI: $10.3892 / \mathrm{ol} .2019 .10915$

\begin{abstract}
Guanine nucleotide exchange factor T (GEFT), a member of the Rho guanine nucleotide exchange factor family, is expressed in a variety of tumors. In the present study, the expression and clinical significance of GEFT in malignant digestive tract tumors was assessed. Tumor and adjacent control samples from 180 patients were tested. Positive GEFT expression rates were $80,83.33$ and $86.67 \%$ in esophageal squamous carcinoma (ESCC), gastric carcinoma (GC) and colorectal cancer (CRC), respectively. GEFT expression was associated with diffuse type carcinoma according to the Lauren classification $\left(\chi^{2}=12.525, \mathrm{P}=0.002\right)$ and tumor-node-metastasis (TNM) stages III/IV $\left(\chi^{2}=4.033, \mathrm{P}=0.045\right)$ in $\mathrm{GC}$, and with vessel carcinoma embolus $\left(\chi^{2}=7.890, \mathrm{P}=0.005\right)$ and lymph node metastasis $\left(\chi^{2}=5.455, \mathrm{P}=0.020\right)$ in $\mathrm{CRC}$, but was not associated with other clinicopathological parameters. Patients with high levels of GEFT protein expression had a less favorable outcome compared with patients with low levels of GEFT expression in patients with $\mathrm{CRC}\left(\chi^{2}=3.876, \mathrm{P}=0.049\right)$. However, a significant association was not found between GEFT expression and overall survival in patients with $\operatorname{ESCC}\left(\chi^{2}=0.040, \mathrm{P}=0.842\right)$ or $\mathrm{GC}\left(\chi^{2}=0.501, \mathrm{P}=0.479\right)$. The rate of human epidermal growth factor receptor 2 upregulation in patients with GC was $13.33 \%$ and it was associated with nerve invasion $\left(\chi^{2}=4.005, \mathrm{P}=0.045\right)$ and TNM stages III/IV $\left(\chi^{2}=5.600, \mathrm{P}=0.018\right)$. Mismatch repair protein (MMRP) defect was observed in six cases, and the KRAS mutation rate was $26.67 \%$ in patients with CRC. GEFT expression was significantly correlated with MMRP $(\mathrm{r}=-0.285$, $\mathrm{P}=0.027)$ and KRAS mutation in patients with CRC $(\mathrm{r}=0.697$, $\mathrm{P}<0.001)$. These findings revealed frequent GEFT upregulation
\end{abstract}

Correspondence to: Dr Qingxin Xia, Department of Pathology, The Affiliated Cancer Hospital of Zhengzhou University, Henan Cancer Hospital, 127 Dongming Road, Zhengzhou, Henan 450008, P.R. China

E-mail: tudou414135404@163.com

Key words: guanine nucleotide exchange factor T, human epidermal growth factor receptor-2, microsatellite instability, KRAS, digestive tract malignant tumor, esophageal squamous carcinoma, gastric carcinoma and colorectal cancer in malignant digestive tract tumors, which may have promoted tumor development. GEFT expression in CRC may be associated with microsatellite instability and $K R A S$ mutation status, suggesting that GEFT may be a potential therapeutic target for patients with CRC.

\section{Introduction}

Guanine nucleotide exchange factor T (GEFT) is a member of the Rho guanine nucleotide exchange factor family, and is capable of activating RhoA, Rac1 and Cdc42 by catalyzing the exchange of Rho-bound GDP for GTP (1). GEFT is highly expressed in excitable tissues such as the brain, heart and muscle, and it modulates the myogenic vs. adipogenic cell fate decision of progenitor mesenchymal cells, thus regulating muscle regeneration, myogenesis and adipogenesis (2).

GEFT is located on chromosome $12 \mathrm{q} 13.3$, a region frequently amplified in sarcomas (3). High copy numbers of the gene for GEFT were observed in rhabdomyosarcoma samples in microarray-based comparative genomic hybridization $(4,5)$. Immunohistochemical analyses suggested that GEFT protein levels were upregulated in rhabdomyosarcoma samples, and was associated with disease aggressiveness and metastasis (6). Furthermore, the mRNAs encoding p63RhoGEF and GEFT, which are derived from the same gene, were both present in the same individual cells (7). Notably, GPR116 regulates cell motility and morphology through the p63RhoGEF-RhoA/Rac1 pathway in the breast carcinoma cell line MDA-MB-231 cells in vitro (8). In these cells, p63RhoGEF mediated the formation of a single polarized lamellipodium which is required for chemotactic migration (9). GEFT protein levels are also increased during differentiation of neuroblastoma cells, where exogenous GEFT expression promotes neurite outgrowth (10). Therefore, GEFT is expressed in a variety of tumors and may be involved in their occurrence and development.

Malignant digestive tract tumors, including gastric malignancy, intestinal malignant tumor and malignant tumor of the esophagus are increasingly prevalent, and seriously threaten patient health (11). Esophageal squamous cell carcinoma (ESCC) is a potentially lethal malignancy with a $15-34 \%$ 5-year survival rates (12). Despite improvements in imaging, surgical techniques and chemoradiation therapy, effective treatment of patients with ESCC remains challenging (13). In addition, gastric cancer (GC) constitutes a major cause of 
cancer-associated death worldwide, particularly in developing countries (14). The incidence of GC is particularly common in Eastern Asia, particularly in China (15). Amplification and/or upregulation of human epidermal growth factor receptor-2 (HER2, also known as ERBB2) is observed in 6.1-23.0\% of GCs. HER2 functions as a proto-oncogene and encodes a transmembrane receptor tyrosine kinase expressed in different types of solid tumors (16-18). However, the prognostic value of HER2 status in GC remains controversial.

Colorectal cancer (CRC) comprises the third most common malignancy in adults worldwide, accounting for 1.36 million cases, after lung cancer (1.8 million) and breast cancer (1.6 million) (19). The mechanism underlying the development of CRC involves two distinct pathways: Chromosomal $(85 \%)$ or microsatellite instability (MSI) $(15 \%)(20,21)$. MSI is a molecular fingerprint of a deficient DNA mismatch repair (MMR) system. The inheritance of a germline mutation in one of the MMR genes $M L H 1, M S H 2, M S H 6$ or $P M S 2$ causes MSI (22-25). Analysis of the encoded MMR proteins (MMRP) by immunohistochemistry (IHC) or MSI testing is used to evaluate MSI (26). KRAS, a member of the RAS family of GTPases, is a small GTPase that is also frequently mutated in a wide range of different types of cancer, including CRC (27). Numerous studies have confirmed that patients with KRAS mutations do not benefit from anti-epidermal growth factor receptor therapy (28-30).

To identify the key factors involved in the occurrence and development of digestive tract tumors, the expression of GEFT in digestive tract tumors on a global scale was assessed. In addition, the association between GEFT expression and the clinicopathological parameters of these patients was determined.

\section{Materials and methods}

Patients and tissue specimen. A total of 180 formalin-fixed paraffin-embedded tumor samples (60 ESCC, 60 gastric adenocarcinoma and 60 colorectal adenocarcinoma) were included in the present study. In addition, 180 matched control samples were selected from normal mucosal tissues $\geq 5 \mathrm{~cm}$ away from the tumor. The 60 ESCC samples consisted of 43 males and 17 females, aged 43-81 years with a median age of 65 years. The GC samples were from 46 males and 14 females, aged 31-79 years with a median age of 61 years. The CRC samples were obtained from 27 females and 33 males, with an age range of 38-87 years and a median age of 61 years. The sections were immersed in hematoxylin for $3 \mathrm{~min}$ and in eosin for $5 \mathrm{sec}$ at room temperature for hematoxylin and eosin and staining (H\&E). H\&E sections were independently analyzed by two senior gastrointestinal pathologists. All patients were categorized according to the 7th American Joint Committee on Cancer Tumor-Node-Metastasis (TNM) stage (31). All samples were collected after surgery at the Department of Pathology, Henan Cancer Hospital (Zhengzhou, China) between August and November 2016. Clinical follow-up information was obtained by telephone from the surgical date till May 2019. The total follow-up period was up to 33 months post-surgery. Based on the hematoxylin and eosin slides, two representative fields were selected for each tumor sample. Tissue samples containing the selected fields were embedded in paraffin blocks. Each area was confirmed to contain $\geq 70 \%$ tumor cells. Sample blocks were sectioned $(4 \mu \mathrm{m})$ for further use in IHC analysis. The purpose of the present research was explained to the participants, who all signed a written consent prior to the study. The present study was approved by the Institutional Ethics Committee of the Affiliated Cancer Hospital of Zhengzhou University.

Experimental reagents. Rabbit polyclonal antibody against human GEFT (1:150; cat. no. ab127690; Abcam) and mouse monoclonal antibody against human HER2 (1:500; cat.no.ab134182; Abcam) were used for IHC. Antibodies against MMRPs, which included MLH1 (cat. no. GT218907), MSH2 (cat. no. GT210507), MSH6 (cat. no. GT219507) and PMS2 (cat. no. GT215907) were purchased as ready-to-use working stocks (Gene Tech Biotechnology Co., Ltd.). The secondary antibody used was purchased as ready-to-use working stocks (cat. no. SM802; Dako; Agilent Technologies, Inc.) which included dextran and peroxidase-conjugated goat secondary antibodies against rabbit and mouse immunoglobulins.

IHC staining procedure. IHC staining was performed using the EnVision system (Dako; Agilent technologies, GmbH). The tissues were fixed in $10 \%$ formalin at room temperature for $24 \mathrm{~h}$ and embedded in paraffin. Serial sections $(4-\mu \mathrm{m}$ thick) were deparaffinized in xylene and rehydrated in a descending series of alcohol solutions (100, 95, 80 and 70\%) for $5 \mathrm{~min}$ each. The samples were placed in citrate buffer (pH 6.0) for antigen retrieval at $95^{\circ} \mathrm{C}$ for $15 \mathrm{~min}$ and subsequently immersed in $3 \%$ hydrogen peroxide in methanol for $10 \mathrm{~min}$ at room temperature to inhibit endogenous peroxidase activity. The sections were incubated overnight at $4{ }^{\circ} \mathrm{C}$ with each primary antibody. After a washing in PBS, the sections were incubated with the secondary antibody at room temperature for $30 \mathrm{~min}$. For negative controls, each antibody was replaced by phosphate buffered saline. GEFT expression was evaluated using semi-quantitative scores as follows: $0, \leq 5 ; 1,6-35 ; 2,36-65$; and 3, 66-100\%. Staining intensity was scored as follows: 0, no staining; 1, buff; 2 , yellow; and 3 , brown. A final staining score was obtained by multiplying the expression and intensity scores as follow:,$- 0 ;+, 1-3$; $2+, 4-6$; and 3+, 7-9. Samples scored as 0 were negative, a score of 1-3 (1+) represented weak expression and a score of 4-9 (2+/3+) represented significantly increased positive expression (6). Samples were visualized on an Olympus BX-41 light microscope (Olympus Corporation, magnification, x400). All samples were evaluated independently by two pathologists.

For determination of HER 2 expression, the scoring criteria used was adapted from Hofmann et al (32): 0, Absence of color or reaction in $<10 \%$ of neoplastic cells; $1+$, weak and/or incomplete coloring of the membrane in $>10 \%$ of neoplastic cells; $2+$, moderate and/or incomplete coloring of the membrane in $>10 \%$ of neoplastic cells; and $3+$, strong and complete and/or incomplete coloring of the membrane in $>10 \%$ of neoplastic cells. The scores were stratified as follows: 0 and 1+, HER2-negative; 2+, indeterminate; and 3+, HER2-positive. Samples scored as $2+$ were analyzed using fluorescence in situ hybridization (FISH) to confirm HER2 expression. 
FISH. Tissues were analyzed using FISH using a Path Vysion kit (cat. no. 02j01-030; Abbott Pharmaceutical Co. Ltd.). The HER-2 DNA probe is a $190 \mathrm{~kb}$ SpectrumOrange ${ }^{\mathrm{TM}}$ directly labeled fluorescent DNA probe specific for the HER-2/neu gene locus (17q11.2-q12). The Chromosome Enumeration Probe (CEP) 17 DAN probe is a $5.4 \mathrm{~Kb}$ SpectrumGreen directly labeled fluorescent DNA probe specific for the alpha satellite DNA sequence at the centromeric region of chromosome 17(17p11.1-q11.1). The $4 \mu \mathrm{m}$ tissue sections were deparaffinized in xylene, and placed in $100 \%$ alcohol for $5 \mathrm{~min}$, twice at room temperature. Slides were subsequently immersed in pretreatment solution at $80^{\circ} \mathrm{C}$ for $30 \mathrm{~min}$, and then in protease solution at $37^{\circ} \mathrm{C}$ for $10 \mathrm{~min}$ (both form Abbott Pharmaceutical Co., Ltd.). Tissue sections were fixed in $10 \%$ neutral buffered formalin solution at room temperature for $10 \mathrm{~min}$ and dried at $45-50^{\circ} \mathrm{C}$ for 2-5 min. The tissues were denatured in denaturation solution at $72^{\circ} \mathrm{C}$ for $5 \mathrm{~min}$. To each section, $1 \mu \mathrm{l}$ probe, $7 \mu \mathrm{l}$ hybridization mix (50\% formamide, $2 \mathrm{x}$ saline sodium citrate, $10 \%$ dextran sulphate) and $2 \mu 1$ deionized water was added and allowed to hybridize overnight at $37^{\circ} \mathrm{C}$. The sections were immersed in post-hybridization solutions ( $2 \mathrm{x}$ saline sodium citrate $/ 0.3 \% \mathrm{NP}-40$ ) at room temperature and then at $72^{\circ} \mathrm{C}$ for 2 min each. Slides were air dried in the dark and mounted in $10 \mu 1$ DAPI/antifade mounting agent (Abbott Pharmaceutical Co. Ltd.). Slides were imaged with a fluorescence microscope (Olympus, BX53; Olympus Corporation). In each slide, three areas were randomly identified, and the average CEP17 and $H E R 2$ copy number in 20 nuclei at $\mathrm{x} 1,000$ magnification was determined. HER $2 / C E P 17$ copy number ratio $>2.0$ was defined as a positive result.

PCR-capillary electrophoresis. The PCR-capillary electrophoresis method was used to detect MSI in CRC. DNA was extracted from the samples using the QIAamp DNA Mini kit (Qiagen $\mathrm{GmbH}$ ). MSI detection used five microsatellite sites: BAT25, BAT26, D2S123, D5S346 and D17S250, as recommended by the National Cancer Institute (33). The primer sequences were as follows: BAT25 forward, 5'TCG CCTCCAAGAATGTAAGT3' and reverse, 5'TCTGGATTT TAACTATGGCTC3'); BAT26 forward, 5'TGACTACTT TTGACTTCAGCC3' and reverse, 5'AACCATTCAACA TTTTTAACC3'); D2S123 forward, 5'AAACAGGATGCC TGCCTTTA3' and reverse, 5'GGACTTTCCACCTATGGG AC3';, D5S346 forward, 5'ACTCACTCTAGTGATAAA TCGGG3' and reverse, 5'AGCAGATAAGACAAGTATTAC TAG3'; and D17S250 forward, 5'GGAAGAATCAAATAG ACAAT3' and reverse, 5'GCTGGCCATATATATATTTAA ACC 3'. A reaction mixture was composed of: $2 \mu 1$ each of both forward and reverse primers, $10 \mu \mathrm{l}$ DNA polymerase (Gene Tech Biotechnology Co. Ltd.), 1-8 $\mu$ l (50-100 ng) template DNA and deionized water to a final reaction volume of $20 \mu \mathrm{l}$. The PCR thermocycling conditions were as follows: Denaturation, $42^{\circ} \mathrm{C}, 5 \mathrm{~min}$ followed by $94^{\circ} \mathrm{C}, 5 \mathrm{~min} ; 40$ cycles of $94^{\circ} \mathrm{C}$ for $15 \mathrm{sec}, 55^{\circ} \mathrm{C}$ for $25 \mathrm{sec}$, and $72^{\circ} \mathrm{C}$ for $50 \mathrm{sec}$; and a final extension step at $72^{\circ} \mathrm{C}$ for $10 \mathrm{~min}$. The PCR products were subsequently separated by capillary electrophoresis on an ABI 3500XL Genetic Analyzer (Applied Biosystems; Thermo Fisher Scientific, Inc.). The results were analyzed using GeneMapper version 4.1 (Applied Biosystems; Thermo Fisher Scientific, Inc.). According to the MSI test results, patients with CRC could be divided into three groups: High frequency MSI (MSI-H), where two or more genes showed instability; low frequency MSI (MSI-L), where only one locus showed gene deletion; and microsatellite stable (MSS), with no gene loss.

Quantitative PCR ( $q P C R)$. Extracted DNA was assayed by qPCR using the human $K R A S$ gene mutation detection kit (Amoy Diagnostics, Co., Ltd.). KRAS mRNA expression was analyzed using TaqMan probes (Amoy Diagnostics, Co., Ltd.; sequences not provided). Assays were performed in triplicate on an ABI Prism 7000 cycler (Applied Biosystems; Thermo Fisher Scientific, Inc.). $\beta$-actin was used as the internal control forward, 5'CCTTCAACACCCCAGCCA3' and reverse 5'ACC CCTCGTAGATGGGCAC3'. The thermocycling conditions were: $95^{\circ} \mathrm{C}$ for $5 \mathrm{~min}$; followed by 15 cycles of $95^{\circ} \mathrm{C}$ for $25 \mathrm{sec}$, $64^{\circ} \mathrm{C}$ for $20 \mathrm{sec}$ and $72^{\circ} \mathrm{C}$ for $20 \mathrm{sec} ; 31$ cycles of $93^{\circ} \mathrm{C}$ for $25 \mathrm{sec}, 60^{\circ} \mathrm{C}$ for $35 \mathrm{sec}$ and $72^{\circ} \mathrm{C}$ for $20 \mathrm{sec}$; and a final extension step of $72^{\circ} \mathrm{C}$ for $10 \mathrm{~min}$. The FAM and HEX signals were collected during the $60^{\circ} \mathrm{C}$ step. KRAS gene expression was calculated using the $2^{-\Delta \Delta \mathrm{Cq}}$ method according to the manufacturer's protocol.

Statistical analysis. SPSS version 21.0 (IBM Corp.) was used to analyze all statistical data. Statistical significance was determined using a $\chi^{2}$ or Fisher's exact test. The correlations between GEFT/HER-2/MMRP/KRAS expression and the clinicopathological factors were determined using the same methods. The correlation between GEFT and HER-2/MMRP/KRAS was determined using Spearman's rank correlation. Kaplan-Meier and log-rank methods were used to calculate overall survival (OS) rates, and the OS curves were compared with the log-rank test. $\mathrm{P}<0.05$ was considered to indicate a statistically significant difference.

\section{Results}

GEFT expression is elevated in patients with ESCC. Positive GEFT protein expression rate in ESCC samples was $80 \%$, which was significantly higher than the normal control samples ( $100 \%$ negative; $\left.\chi^{2}=80.000, \mathrm{P}<0.001\right)$. Representative images of GEFT protein expression in ESCC is shown in Fig. 1A, and the negative control samples are shown in (Fig. 1B). In the 60 cases of ESCC, the GEFT (1+) expression rate was $56.67 \%(34 / 60)$ and the GEFT (2+) expression rate was $23.33 \%$ (14/60). There were no cases of GEFT (3+) expression. The GEFT-negative expression rate was $20 \%$ $(12 / 60)$ (Table I).

Association between the clinicopathological parameters of ESCC with GEFT expression. Table II shows the association between GEFT expression and ESCC clinicopathological factors. Although the expression of GEFT was significantly higher in tumor tissues compared with the control samples, GEFT levels were not associated with any of the assessed clinicopathological parameters (all P>0.05; Table II).

Association between GEFT expression and OS in patients with ESCC. Of the 60 patients with ESCC included in the present study, two patients were lost to follow-up, 38 cases 
A

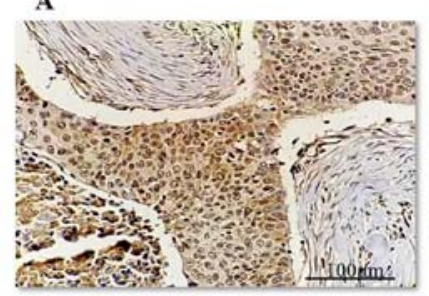

C

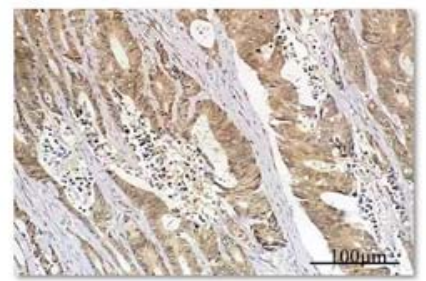

E

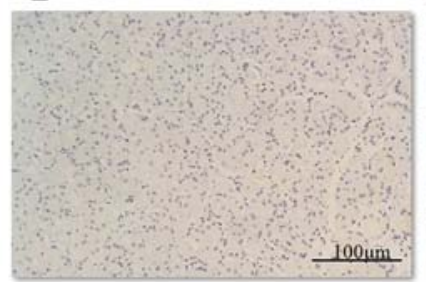

G

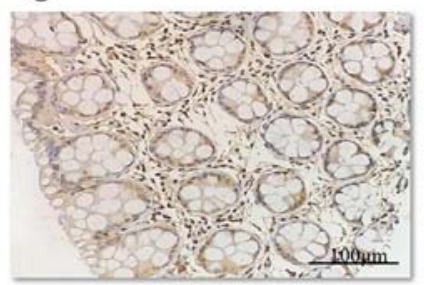

B

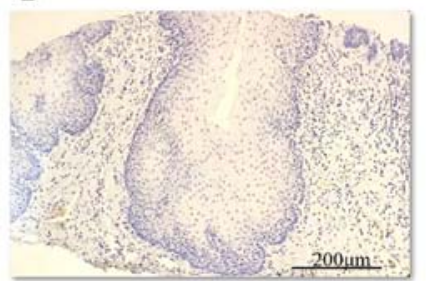

D

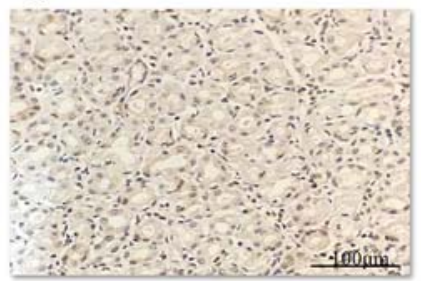

F

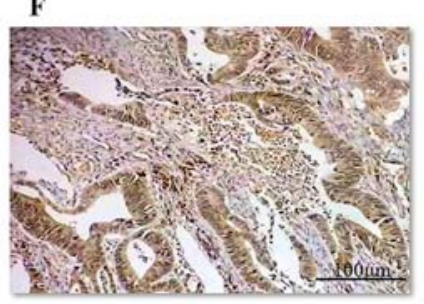

H

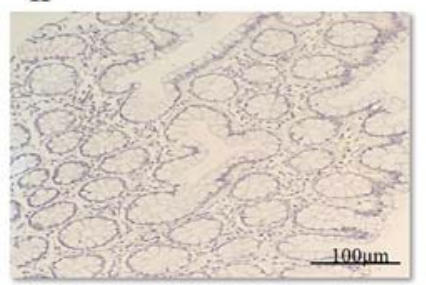

Figure 1. Immunohistochemical staining for GEFT in ESCC, GC and CRC shows positivity in the cytoplasm. (A) GEFT-protein positivity in ESCC (2+). Scale bar, $100 \mu \mathrm{M}$. (B) GEFT-protein negativity in normal esophageal mucosa. Scale bar, $200 \mu \mathrm{M}$. (C) GEFT-protein positivity in GC (3+). Scale bar, $100 \mu \mathrm{M}$. (D) GEFT-protein positivity in normal gastric mucosa (1+). Scale bar, $100 \mu \mathrm{M}$. (E) GEFT-protein negativity in normal gastric mucosa Scale bar, $100 \mu \mathrm{M}$. (F) GEFT-protein positivity in CRC (3+). Scale bar, $100 \mu \mathrm{M}$. (G) GEFT-protein positivity in normal intestinal mucosa (1+). Scale bar, $100 \mu \mathrm{M}$. (H) GEFT-protein negativity in normal intestinal mucosa. Scale bar, $100 \mu \mathrm{M}$. GEFT, guanine nucleotide exchange factor T; ESCC, esophageal squamous carcinoma; GC, gastric carcinoma; CRC, colorectal cancer; 1+, weak expression; $2+/ 3+$, significantly increased positive expression.

survived and 20 died. The collective OS time of all the patients ranged from 9-33 months, with a median overall survival time of 32 months. Among the 14 patients with GEFT overexpression (2+/3+), five patients died while nine survived. In the patient group with lower GEFT expression $(-/ 1+), 44$ patients were available for follow-up. Of those patients, 15 died and 29 survived. There was no significant association between GEFT expression and OS $\left(\chi^{2}=0.040\right.$, $\mathrm{P}=0.842$; Fig. 2A).

GEFT expression is increased in patients with GC. GEFT protein expression in $60 \mathrm{GC}$ tissues and 60 normal gastric mucosa samples was observed by IHC. The positive GEFT expression rate in GC tissues was $83.33 \%$, which was significantly higher $\left(\chi^{2}=61.788, \mathrm{P}<0.001\right)$ compared with the normal control samples. Of the control samples, seven expressed GEFT protein (1+), but the rest were negative. Fig. 1C

shows positive GEFT-protein expression in GC (3+); and Fig. 1D and E show 1+ and negative GEFT-protein expression, respectively, in normal gastric mucosa samples. Among the $60 \mathrm{GC}$ tissues samples, the GEFT (1+) expression rate was $28.33 \%$ (17/60), the GEFT (2+) expression rate was $38.33 \%$ $(23 / 60)$ and the GEFT (3+) expression rate was $16.67 \%(10 / 60)$. The GEFT-negative expression rate was $16.67 \%(10 / 60)$ in GC tissues (Table I).

Association between the clinicopathological parameters of GC and GEFT expression. Table III shows the association between GEFT expression and the clinicopathological features of gastric adenocarcinoma. GEFT expression was associated with Lauren stage $\left(\chi^{2}=12.525, \mathrm{P}=0.002\right)$ and TNM stage $\left(\chi^{2}=4.033, P=0.045\right.$; Table III $)$, but was not associated with any of the other clinicopathological parameters. The expression of GEFT protein was highest (80\%) in the diffuse Lauren stage classification type, lowest (25\%) in the intestinal type and 60\% in the mixed type. GEFT protein was moderately expressed $(2+/ 3+)$ in $40.74 \%(11 / 27)$ of TNM stage I/II samples, whereas expression $(2+/ 3+)$ was lower $(66.67 \%, 22 / 33)$ in TNM stage III/IV samples (Table III).

Association between GEFT expression and OS in patients with GC. Of the 60 patients with GC enrolled in the study, 5 cases were lost during follow-up, 35 patients survived, and 20 patients died. The collective OS time of all the patients ranged from 12-33 months, with a median overall survival time of 32 months. In the GEFT overexpression group (2+/3+), survival data for 30 patients were collected. Among them, 12 patients died and 18 survived. In the low GEFT expression group (-/1+), survival data for 25 patients were acquired of which eight patients died and 17 survived. Although the survival rates of patients with GC with higher GEFT expression was lower compared with patients with lower GEFT expression (Fig. 2B), there was no significant association between GEFT expression and survival in patients with GC $\left(\chi^{2}=0.501, \mathrm{P}=0.479\right)$.

HER 2 expression in patients with GC. HER 2 expression and the mRNA and protein levels in GC are shown in Fig. 3. In the present study, HER 2 protein expression was $3+$ in 5 of the 60 cases of GC, $2+$ in 18 cases, $1+$ in 20 cases and 0 in 17 cases. The expression of HER 2 protein was absent in all of the normal control samples (Table IV). In cases where the sample was scored as 2+, FISH was used to detect HER2 gene amplification. Of these samples, 3 of 18 showed HER2 gene amplification, whereas normal control gastric mucosa samples were negative for HER2 amplification (Table IV). Therefore, the HER2+ rate in the $60 \mathrm{GC}$ samples was $13.33 \%$ $(8 / 60)$ (Table IV).

The association between HER2 protein expression and the clinicopathological features in patients with gastric adenocarcinoma is shown in Table III. HER2 expression was associated with nerve invasion $\left(\chi^{2}=4.005, \mathrm{P}=0.045\right)$ and TNM stage $\left(\chi^{2}=5.600, \mathrm{P}=0.018\right)$, but was not associated with the other clinicopathological parameters. The expression of HER2 protein was higher in cases with nerve invasion (24.14\%) compared with cases without nerve invasion (3.22\%). HER2 expression was absent in TNM stage I/II 
Table I. GEFT protein expression in ESCC, GC and CRC samples.

\begin{tabular}{|c|c|c|c|c|c|c|}
\hline \multirow[b]{2}{*}{ GEFT } & \multicolumn{2}{|c|}{ ESCC } & \multicolumn{2}{|c|}{$\mathrm{GC}$} & \multicolumn{2}{|c|}{$\mathrm{CRC}$} \\
\hline & $\begin{array}{c}\text { Tumor samples } \\
\mathrm{n}(\%)\end{array}$ & $\begin{array}{c}\text { Control samples } \\
\mathrm{n}(\%)\end{array}$ & $\begin{array}{c}\text { Tumor samples } \\
\mathrm{n}(\%)\end{array}$ & $\begin{array}{c}\text { Control samples } \\
\mathrm{n}(\%)\end{array}$ & $\begin{array}{c}\text { Tumor samples } \\
\mathrm{n}(\%)\end{array}$ & $\begin{array}{c}\text { Control samples } \\
\mathrm{n}(\%)\end{array}$ \\
\hline- & $12(20.00)$ & $60(100.00)$ & $10(16.67)$ & $53(88.33)$ & $8(13.33)$ & $59(98.33)$ \\
\hline $1+$ & $34(56.67)$ & $0(0.00)$ & $17(28.33)$ & 7 (11.67) & 19 (31.67) & 1 (1.67) \\
\hline $2+$ & $14(23.33)$ & $0(0.00)$ & $23(38.33)$ & $0(0.00)$ & $27(45.00)$ & $0(0.00)$ \\
\hline $3+$ & $0(0.000)$ & $0(0.00)$ & $10(16.67)$ & $0(0.00)$ & $6(10.00)$ & $0(0.00)$ \\
\hline$\chi^{2}$ & \multicolumn{2}{|c|}{80.000} & \multicolumn{2}{|c|}{61.788} & \multicolumn{2}{|c|}{87.896} \\
\hline P-value & \multicolumn{2}{|c|}{$<0.001^{\mathrm{a}}$} & \multicolumn{2}{|c|}{$<0.001^{\mathrm{a}}$} & \multicolumn{2}{|c|}{$<0.001^{\mathrm{a}}$} \\
\hline
\end{tabular}

${ }^{\mathrm{a}} \mathrm{P}<0.01$. GEFT, guanine nucleotide exchange factor T; ESCC, esophageal squamous carcinoma; GC, gastric carcinoma; CRC, colorectal cancer.
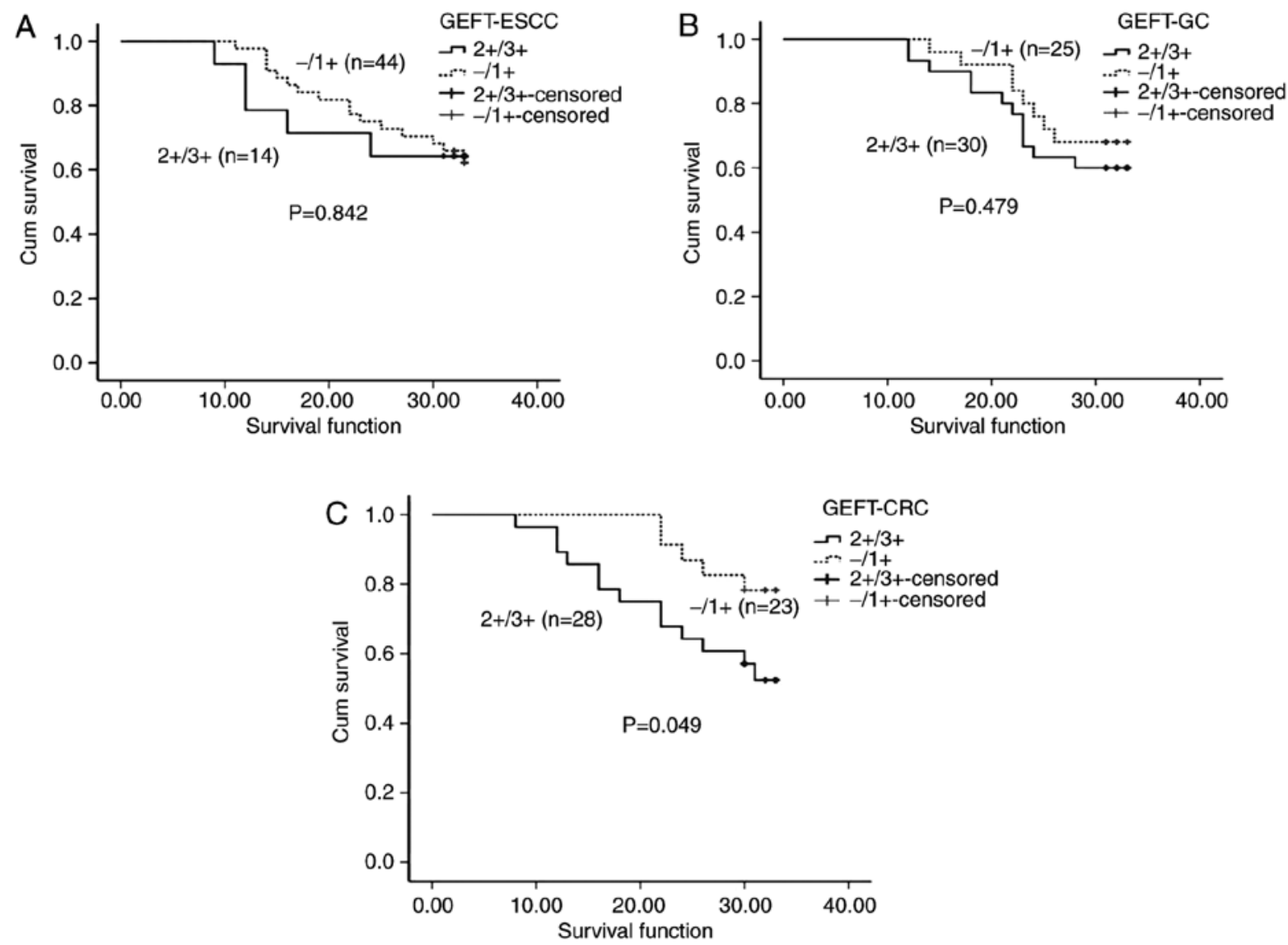

Figure 2. Kaplan-Meier survival curves comparing survival time for patients with upregulated GEFT expression with GEFT protein downregulation. There was no significant association between GEFT expression and overall survival in patients with (A) ESCC $\left(\chi^{2}=0.040, \mathrm{P}=0.842\right)$ and (B) patients with GC $\left(\chi^{2}=0.501, P=0.479\right)$. (C) Patients with CRC with upregulated expression of GEFT $(2+/ 3+)$ following surgery had a significantly reduced overall survival time compared with patients with low GEFT levels $(-/ 1+)\left(\chi^{2}=3.876, \mathrm{P}=0.049\right)$. GEFT, guanine nucleotide exchange factor T; ESCC, esophageal squamous carcinoma; GC, gastric carcinoma; CRC, colorectal cancer.

samples, and its expression was relatively lower in TNM stage III/IV samples $(24.24 \%, 8 / 33)$. Of the 8 HER2 positive GC samples, 3 samples were scored as 1+ GEFT expression, 1 case was scored as 2+ GEFT expression, 1 case was scored as 3+ GEFT expression, and 3 cases scored as negative for GEFT expression. No significant correlation was identified between the levels of GEFT and HER2 expression ( $r=0.197$, $\mathrm{P}=0.132$ ) (Table V).
GEFT is highly expressed in patients with CRC. In the $60 \mathrm{CRC}$ samples, 52 samples were positive for GEFT protein expression, with 6 samples rated as strongly positive (3+), 27 rated as positive $(2+)$ and 19 rated as weakly positive $(1+)$. The overall GEFT protein expression rate was $86.67 \%(52 / 60)$ which was significantly higher than the control group $\left(\chi^{2}=87.896\right.$, $\mathrm{P}<0.001)$, where only 1 of 60 normal intestinal mucosa samples showed weakly positive GEFT expression (1+) (Table I). Fig. 1F 
Table II. Association between GEFT protein expression and clinicopathologic features in patients with esophageal squamous cell carcinoma.

\begin{tabular}{|c|c|c|c|c|c|}
\hline \multirow[b]{2}{*}{ Variable } & \multirow[b]{2}{*}{ Cases } & \multicolumn{2}{|c|}{ GEFT } & \multirow[b]{2}{*}{$\chi^{2}$ value } & \multirow[b]{2}{*}{ P-value } \\
\hline & & $-/ 1+(\%)$ & $2+/ 3+(\%)$ & & \\
\hline Sex & & & & $<0.001$ & 1.000 \\
\hline Male & 43 & $33(76.74)$ & $10(23.26)$ & & \\
\hline Female & 17 & $13(76.47)$ & $4(23.53)$ & & \\
\hline Age, years & & & & 0.497 & 0.481 \\
\hline$\geq 60$ & 45 & $33(73.33)$ & $12(26.67)$ & & \\
\hline$<60$ & 15 & $13(86.67)$ & $2(13.33)$ & & \\
\hline Location & & & & 0.542 & 0.462 \\
\hline Upper esophagus & 5 & $5(100.00)$ & $0(0.00)$ & & \\
\hline Middle/lower esophagus & 55 & $41(74.55)$ & $14(25.45)$ & & \\
\hline Tumor diameter, $\mathrm{cm}$ & & & & 0.001 & 0.982 \\
\hline$\leq 3$ & 17 & $13(76.47)$ & $4(23.53)$ & & \\
\hline$>3$ & 43 & $33(76.74)$ & $10(23.26)$ & & \\
\hline Histological type & & & & 3.828 & 0.281 \\
\hline Ulcerative type & 28 & $21(75.00)$ & $7(25.00)$ & & \\
\hline Medullary type & 21 & $19(90.48)$ & $2(9.52)$ & & \\
\hline Constrictive type & 9 & $4(44.44)$ & $5(55.56)$ & & \\
\hline Fungating type & 2 & $2(100.00)$ & $0(0.00)$ & & \\
\hline Tumor differentiation & & & & 0.836 & 0.361 \\
\hline Moderate/well & 46 & $34(73.91)$ & $12(26.09)$ & & \\
\hline Poor & 14 & $12(85.71)$ & $2(14.29)$ & & \\
\hline Depth of invasion & & & & 0.023 & 0.879 \\
\hline $\mathrm{T} 1 / \mathrm{T} 2$ & 12 & $9(75.00)$ & $3(25.00)$ & & \\
\hline $\mathrm{T} 3 / \mathrm{T} 4$ & 48 & $37(77.08)$ & $11(22.92)$ & & \\
\hline Nerve invasion & & & & 0.586 & 0.444 \\
\hline Yes & 13 & $11(84.62)$ & $2(15.38)$ & & \\
\hline No & 47 & $35(74.47)$ & $12(25.53)$ & & \\
\hline Vessel carcinoma embolus & & & & 2.402 & 0.121 \\
\hline Yes & 28 & $24(85.71)$ & $4(14.29)$ & & \\
\hline No & 32 & $22(68.75)$ & $10(31.25)$ & & \\
\hline TNM stage & & & & 0.106 & 0.744 \\
\hline I and II & 32 & $24(75.00)$ & $8(25.00)$ & & \\
\hline III and IV & 28 & $22(78.57)$ & $6(21.43)$ & & \\
\hline Lymph node metastasis & & & & 0.034 & 0.854 \\
\hline Yes & 27 & $21(77.78)$ & $6(22.22)$ & & \\
\hline No & 33 & $25(75.76)$ & $8(24.24)$ & & \\
\hline
\end{tabular}

GEFT, guanine nucleotide exchange factor T; TNM, Tumor-Node-Metastasis.

shows GEFT-protein positivity in CRC (3+), and Fig. $1 \mathrm{G}$ and $\mathrm{H}$ show GEFT protein expression (1+) and negative expression in normal intestinal mucosa, respectively.

Association between the clinicopathological parameters of CRC and GEFT expression. Table VI shows the association between GEFT expression and the clinicopathological factors of CRC. GEFT protein expression was associated with vessel carcinoma embolus $\left(\chi^{2}=7.890, \mathrm{P}=0.005\right)$ and lymph node metastasis $\left(\chi^{2}=5.455, \mathrm{P}=0.020\right)$, but was not associated with any of the other clinicopathological parameters. Among the samples with vessel carcinoma embolus (23/32) or lymph node metastasis (21/30), high GEFT protein expression $(2+/ 3+)$ was significantly higher than in samples without vessel carcinoma embolus (10/28) or lymph node metastasis (12/30).

Association between GEFT expression and OS in CRC. Survival data were collected for 51 of the 60 patients with CRC 
Table III. Association between GEFT protein expression, HER2 expression and clinicopathologic features in patients with gastric cancer.

\begin{tabular}{|c|c|c|c|c|c|}
\hline Variable & Cases & GEFT $2+/ 3+(\%)$ & P-value & HER 2+ (\%) & P-value \\
\hline Sex & & & 0.297 & & 0.142 \\
\hline Male & 46 & $27(58.70)$ & & $4(8.70)$ & \\
\hline Female & 14 & $6(42.86)$ & & $4(28.57)$ & \\
\hline Age, years & & & 0.693 & & 0.898 \\
\hline$\geq 60$ & 35 & $20(57.14)$ & & $4(11.43)$ & \\
\hline$<60$ & 25 & $13(52.00)$ & & $4(16.00)$ & \\
\hline Tumor diameter & & & 0.373 & & 0.644 \\
\hline$\geq 5 \mathrm{~cm}$ & 34 & $17(50.00)$ & & $5(14.71)$ & \\
\hline$<5 \mathrm{~cm}$ & 26 & $16(61.54)$ & & $3(11.54)$ & \\
\hline Lauren stage & & & $0.002^{\mathrm{b}}$ & & 0.065 \\
\hline Diffuse type & 20 & $16(80.00)$ & & $3(15.00)$ & \\
\hline Intestinal type & 20 & $5(25.00)$ & & $5(25.00)$ & \\
\hline Mixed type & 20 & $12(60.00)$ & & $0(0.00)$ & \\
\hline Tumor differentiation & & & 0.053 & & 0.577 \\
\hline Moderate/well & 21 & $8(38.10)$ & & $4(19.05)$ & \\
\hline Poor & 39 & $25(64.10)$ & & $4(10.26)$ & \\
\hline Mucinous adenocarcinoma & & & 0.807 & & 0.811 \\
\hline Yes & 21 & $12(57.14)$ & & $2(9.52)$ & \\
\hline No & 39 & $21(53.85)$ & & $6(15.38)$ & \\
\hline Depth of invasion & & & 0.481 & & 1.000 \\
\hline $\mathrm{T} 1 / \mathrm{T} 2$ & 5 & $2(40.00)$ & & $1(20.00)$ & \\
\hline $\mathrm{T} 3 / \mathrm{T} 4$ & 55 & $31(56.36)$ & & $7(12.73)$ & \\
\hline Nerve invasion & & & 0.035 & & $0.045^{\mathrm{a}}$ \\
\hline Yes & 29 & $20(68.97)$ & & $7(24.14)$ & \\
\hline No & 31 & $13(41.94)$ & & $1(3.22)$ & \\
\hline Vessel carcinoma embolus & & & 0.925 & & 0.256 \\
\hline Yes & 47 & $26(55.32)$ & & $8(17.02)$ & \\
\hline No & 13 & $7(53.85)$ & & $0(0.00)$ & \\
\hline TNM stage & & & $0.045^{\mathrm{a}}$ & & $0.018^{\mathrm{a}}$ \\
\hline I and II & 27 & $11(40.74)$ & & $0(0.00)$ & \\
\hline III and IV & 33 & $22(66.67)$ & & $8(24.24)$ & \\
\hline Lymph node metastasis & & & 1.000 & & 0.150 \\
\hline Yes & 49 & $27(55.10)$ & & $8(16.33)$ & \\
\hline No & 11 & $6(54.55)$ & & $0(0.00)$ & \\
\hline Distant metastasis & & & 0.386 & & 1.000 \\
\hline Yes & 2 & $0(0.00)$ & & $0(0.00)$ & \\
\hline No & 58 & $33(56.90)$ & & $8(13.80)$ & \\
\hline
\end{tabular}

${ }^{\mathrm{a}} \mathrm{P}<0.05,{ }^{\mathrm{b}} \mathrm{P}<0.01$. GEFT, guanine nucleotide exchange factor $\mathrm{T}$; TNM, Tumor-Node-Metastasis; $2+/ 3+$, significantly increased positive expression.

in the present study. The remaining 9 cases were lost during follow-up. Of these cases, 34 patients survived, and 17 patients died. The collective OS time ranged from 8-33 months, with a median overall survival time of 30 months. GEFT protein upregulation $(2+/ 3+)$ was detected in 33 patients with CRC, but survival data was available from only 28 patients, with 5 patients lost to follow-up. In patients with increased GEFT expression, 12 patients died and 16 survived. In the low GEFT expression group $(-/ 1+)$, survival state information was collected for
23 patients. In this group, 5 patients died and 18 survived. The survival rates of patients with CRC with GEFT upregulation was lower compared with patients with lower GEFT expression $\left(\chi^{2}=3.876, P=0.049\right.$; Fig. $\left.2 C\right)$. Additionally, patients with $\mathrm{CRC}$ with upregulated expression of GEFT had a less favorable outcome compared with patients with low expression of GEFT.

MMRPs are expressed in patients with CRC. The expression of the four CRC-associated MMRPs, including MLH1, MSH2, 

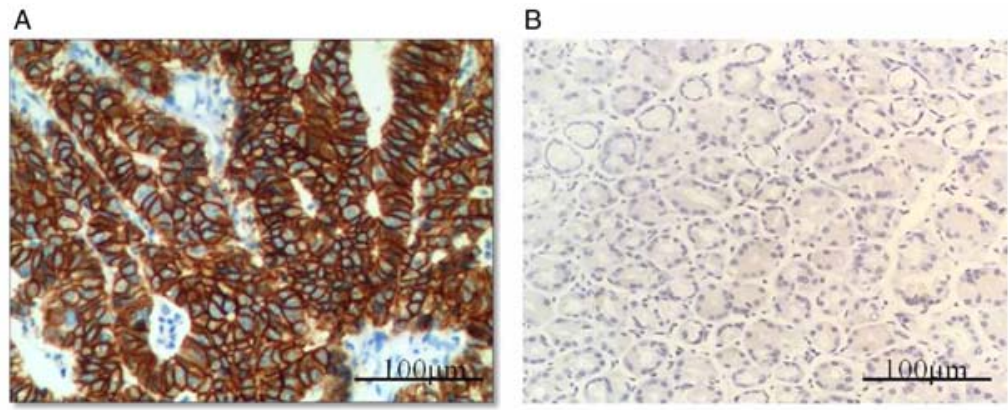

C

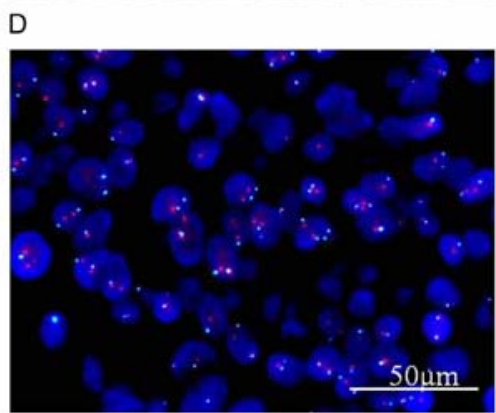

Figure 3. HER2 expression in GC. (A) Expression of HER2 protein was found to be 3+ based on the immunohistochemical staining. (B) Expression of HER2 protein was negative in normal gastric mucosa. (C) HER2 gene (red) expression was amplified in GC, as shown using florescence in situ hybridization (D) HER2 gene expression was absent in normal gastric mucosa. Chromosome 17 centromere locus (CEP17) is shown in green. HER2, human epidermal growth factor receptor-2; GC, gastric carcinoma.
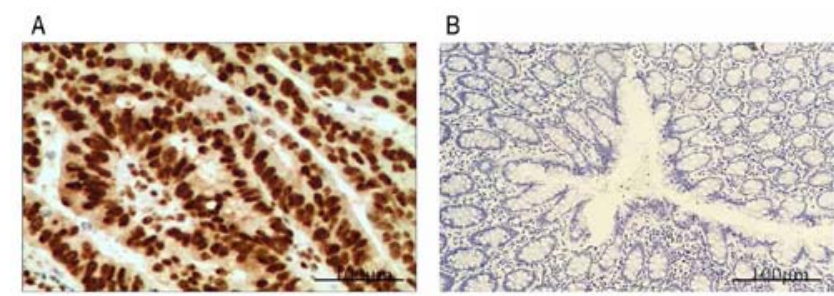

C

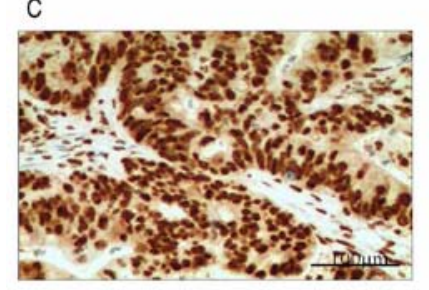

E

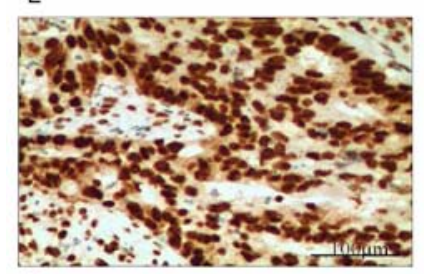

G
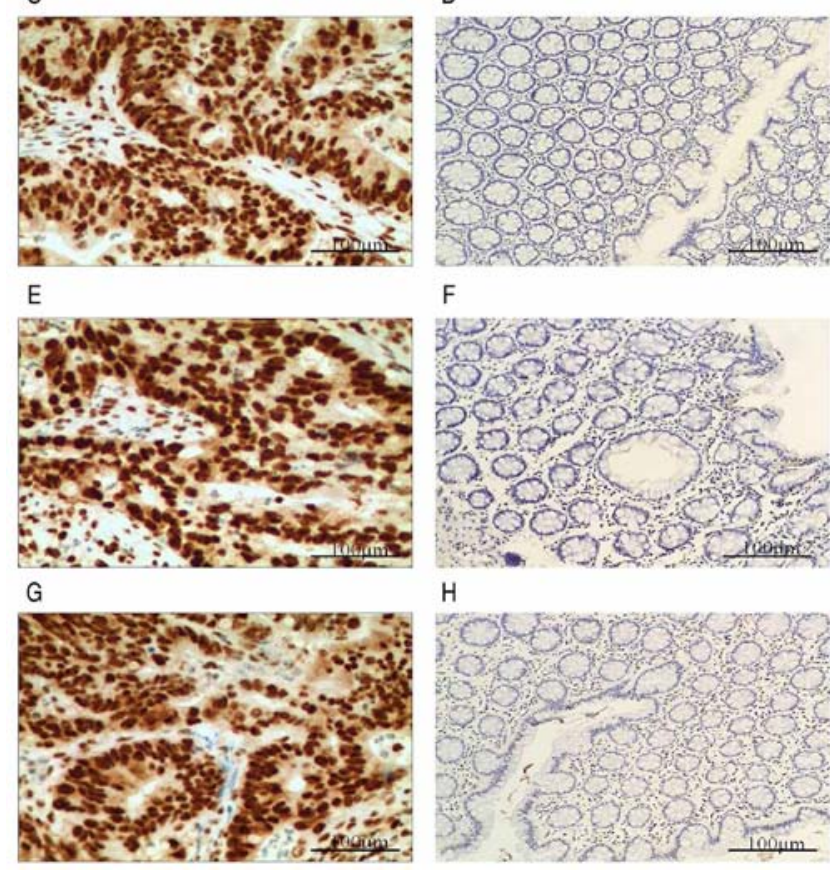

$\mathrm{F}$

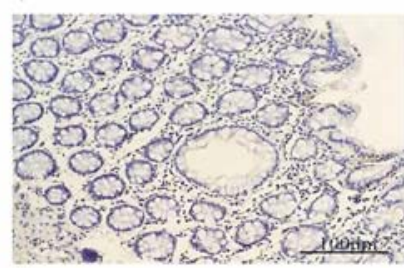

$\mathrm{H}$

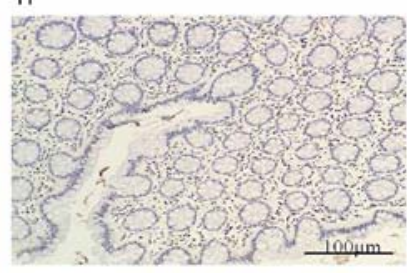

Figure 4. Immunohistochemical staining for mismatch repair protein in colorectal cancer shows positivity in the nucleus. MLH1 expression in (A) CRC tissue and (B) normal intestinal mucosa. MSH2 expression in (C) CRC tissue and (D) normal intestinal mucosa. MSH6 expression in (E) CRC tissue and $(\mathrm{F})$ normal intestinal mucosa. PMS2 expression in (G) CRC tissue and (H) normal intestinal mucosa.
MSH6 and PMS2, were evaluated by IHC. Fig. 4 shows IHC staining of MMRP in CRC. Loss of at least one MMRP was defined as MMRP-defective (MMR-D) and no MMRP loss was defined as MMRP-intact (MMR-I). In the present study, 6 cases of CRC were MMR-D and 54 were MMR-I. Among the MMR-D group, 4 samples displayed loss of PMS2, 1 showed loss of MSH2 and MSH6, and 1 exhibited loss of PMS2 and MLH1 (Table VII).

Comparison of clinicopathological data of the MMR-D and $M M R-I$ groups in colorectal adenocarcinoma. The association between the MMR-D and MMR-I groups in colorectal adenocarcinoma is shown in Table VI. MMR-D incidence was lower in patients with a tumor maximal diameter $\geq 5 \mathrm{~cm}\left(\chi^{2}=5.208, \mathrm{P}=0.022\right.$; Table VI). However, there was significant difference between MMR-D and MMR-I groups in any of the other clinicopathological variables assessed in patients with CRC (Table VI). In the 6 MMR-D cases of CRC, 4 cases were GEFT expression negative, and 2 cases were GEFT expression (2+). The association between GEFT and MMRPs was further examined by correlational analyses, which identified a significant inverse correlation $(\mathrm{r}=-0.285$, $\mathrm{P}=0.027)($ Table V).

MSI in colorectal adenocarcinoma. Among the 60 CRC specimens, 6 samples were MSI-H, 1 was MSI-L and 53 were MSS. Analysis of the microsatellite sites showed that among the MSI-H group, 3 samples exhibited Bat 25 and Bat26 mutations, 1 sample showed Bat25, Bat26 and D5S346 mutations, 1 sample showed Bat25 and D17S250 mutations and 1 sample exhibited Bat 25 and D2S123 mutations. Only one sample is MSI-L with Bat 25 mutations (Table VIII). Using the PCR test results as the standard, the positive conformity rate in the present study was $83.33 \%(5 / 6)$ and the negative conformity rate was $98.15 \%$ (53/54). The coincidence rate between PCR 
Table IV. HER2 protein and gene expression in the GC samples.

\begin{tabular}{lc}
\hline A, Negative & \\
\hline Variable & $\mathrm{n}(\%)$ \\
\hline IHC- & $17(28.34)$ \\
IHC 1+ & $20(33.33)$ \\
IHC 2+, FISH- & $15(25.00)$ \\
Total & $52(86.67)$ \\
\hline
\end{tabular}

B, Positive

\begin{tabular}{ll}
\hline Variable & $\mathrm{n}(\%)$ \\
\hline IHC 2+, FISH+ & $3(5.00)$ \\
IHC 3+ & $5(8.33)$ \\
Total & $8(13.33)$
\end{tabular}

IHC, immunohistochemistry; FISH, fluorescence in situ hybridization.

and IHC was $96.67 \%(58 / 60)$, and the consistency check result $(\kappa)$ was $0.815(\mathrm{P}<0.001)$. The sensitivity of IHC was $83.33 \%(5 / 6)$ and the specificity was $98.15 \%$ (53/54) (Table IX). These results demonstrate that analysis via PCR and IHC are well associated.

KRAS gene mutations in patients with CRC. Mutations in the KRAS gene were detected by qPCR in 16 of the $60 \mathrm{CRC}$ samples (in codon 12 in 13 cases and in codon 13 in 3 cases), with a mutation rate of $26.67 \%$. Specific mutation types and the incidence rates are listed in Table X.

Comparison of clinicopathological data of KRAS gene mutations in patients with CRC. The association between KRAS mutations and clinicopathological features in CRC is listed in Table VI. The KRAS mutation rate was higher in poorly differentiated CRC (62.50\%) compared with well/moderately differentiated samples $\left(21.15 \%, \chi^{2}=4.131, \mathrm{P}=0.042\right)$. No difference in KRAS mutation status was identified with any of the other clinicopathological variables assessed. Among the 16 KRAS gene mutation samples of CRC, 1 sample was scored as $1+$, for 8 samples were scored as $2+, 4$ samples were scored as $3+$, and 3 samples were scored as negative for GEFT protein expression. Further investigation of the association between GEFT expression and KRAS mutation by correlation analyses demonstrated a significant correlation $(r=0.697$, $\mathrm{P}<0.001)$ (Table V).

\section{Discussion}

GEFT was initially identified in 2003 by Guo et al (3), and it regulates cellular processes by catalyzing GDP/GTP exchange on Rho GTPases, including Rac1, Cdc42 and RhoA. These Rho GTPases are essential for cytoskeletal dynamics and are particularly important in migration of cancer cells $(34,35)$. Although GEFT is expressed in a variety of tumors, its expression in
Table V. Association between GEFT and HER-2/MMRP/KRAS.

\begin{tabular}{|c|c|c|c|c|c|c|}
\hline \multirow[b]{2}{*}{ GEFT } & \multicolumn{2}{|c|}{ HER2 } & \multicolumn{2}{|c|}{ MMRP } & \multicolumn{2}{|c|}{$\begin{array}{l}\text { KRAS } \\
\text { mutation }\end{array}$} \\
\hline & + & - & MMRD & MMRI & Yes & No \\
\hline- & 3 & 7 & 4 & 4 & 3 & 5 \\
\hline $1+$ & 3 & 14 & 0 & 17 & 1 & 16 \\
\hline $2+$ & 1 & 22 & 2 & 25 & 8 & 19 \\
\hline $3+$ & 1 & 9 & 0 & 6 & 4 & 2 \\
\hline r-value & 0.197 & & -0.285 & & 0.697 & \\
\hline P-value & 0.132 & & $0.027^{\mathrm{a}}$ & & $<0.001^{\mathrm{b}}$ & \\
\hline
\end{tabular}

${ }^{\mathrm{a}} \mathrm{P}<0.05,{ }^{\mathrm{b}} \mathrm{P}<0.01$. GEFT, guanine nucleotide exchange factor $\mathrm{T}$; MMRD, mismatch repair protein-deficient; MMRI, mismatch repair protein-intact.

malignant digestive tract tumors has not been studied, to the best of our knowledge. The present study found that GEFT protein expression was higher in malignant digestive tract tumors compared with normal tissues. GEFT expression in ESCC samples was higher compared with normal squamous epithelium, but weaker than in tumor samples from patients with GC and CRC. The GEFT-positive samples primarily included samples with 1+ and 2+ GEFT protein expression. However, an association between GEFT expression and the clinicopathological factors of ESCC was not found. In the ESCC cohort, the median survival time was 32 months, which is close to the maximum survival time (33 months). This is the result of a short follow-up time, and thus the majority of patients were still alive. As such, the survival time in the present study is not really indicative of overall survival. This was also true for the CRC and GC cohorts. The association between GEFT protein expression and OS were further analyzed, and there was no significant association between GEFT expression and OS in ESCC. Therefore, increased GEFT protein expression in ESCC samples may not represent an important factor in the pathogenesis of esophageal cancer.

In GC tissues, GEFT protein expression was higher compared with the gastric mucosa. According to Lauren staging, GEFT protein expression was the highest in the diffuse type and lowest in the intestinal type. Several studies have demonstrated that the Lauren stage was closely associated with certain clinicopathological characteristics such as age, sex, tumor size, location, grade, invasion depth, lymphovascular invasion and prognosis of GC $(36,37)$. Patients with intestinal type GC were predominantly older, male, had a smaller tumor size, had relatively well differentiated tumors, and tumors which has less tumor invasion depth and less lymphovascular invasion (37). Compared with proximal, middle and whole stomach, the incidence of intestinal type GC was the highest in distal stomach (37). Specifically, patients with intestinal-type tumors exhibited more favorable outcomes compared with patients with diffuse-type tumors (38-40). The data from the present study suggested that increased GEFT protein expression in diffuse-type samples may be associated with a poor prognosis. Consistently, the expression of GEFT protein was higher in TNM stage III/IV samples $(66.67 \%)$ compared with 
Table VI. Association between GEFT protein expression, MMRD, KRAS mutations and clinicopathologic features in patients with colorectal cancer.

\begin{tabular}{|c|c|c|c|c|c|c|c|}
\hline Variable & Cases & GEFT $2+/ 3+(\%)$ & P-value & MMRD (\%) & P-value & KRAS mutation (\%) & P-value \\
\hline Sex & & & 0.983 & & 0.299 & & 0.907 \\
\hline Male & 33 & $18(54.54)$ & & $5(15.15)$ & & $9(27.27)$ & \\
\hline Female & 27 & $15(55.56)$ & & $1(3.70)$ & & $7(25.93)$ & \\
\hline Age, years & & & 0.875 & & 1.000 & & 0.071 \\
\hline$\geq 60$ & 34 & $19(55.88)$ & & $3(8.82)$ & & $6(17.65)$ & \\
\hline$<60$ & 26 & $14(53.85)$ & & $3(11.54)$ & & $10(38.46)$ & \\
\hline Tumor diameter & & & 1.000 & & $0.022^{\mathrm{a}}$ & & 0.836 \\
\hline$\geq 5 \mathrm{~cm}$ & 40 & $22(55.00)$ & & $1(7.50)$ & & $11(27.50)$ & \\
\hline$<5 \mathrm{~cm}$ & 20 & $11(55.00)$ & & $5(25.00)$ & & $5(25.00)$ & \\
\hline Location & & & 0.523 & & 0.510 & & 0.801 \\
\hline Right hemicolon & 12 & $5(41.67)$ & & $2(16.67)$ & & $3(25.00)$ & \\
\hline Sigmoid colon & 15 & $8(53.33)$ & & $2(13.33)$ & & $5(33.33)$ & \\
\hline Rectum & 33 & $20(60.61)$ & & $2(6.06)$ & & $8(24.24)$ & \\
\hline Tumor differentiation & & & 1.000 & & 1.000 & & $0.042^{\mathrm{a}}$ \\
\hline Moderate/well & 52 & $29(55.76)$ & & $5(9.62)$ & & $11(21.15)$ & \\
\hline Poor & 8 & $4(50.00)$ & & $1(12.50)$ & & $5(62.50)$ & \\
\hline Mucinous adenocarcinoma & & & 1.000 & & 1.000 & & 0.214 \\
\hline Yes & 7 & $4(57.14)$ & & $1(14.29)$ & & $0(0.00)$ & \\
\hline No & 53 & $29(54.72)$ & & $5(9.43)$ & & $16(30.19)$ & \\
\hline Depth of invasion & & & 0.668 & & 0.919 & & 1.000 \\
\hline $\mathrm{T} 3$ & 14 & $7(50.00)$ & & $2(14.29)$ & & $4(28.57)$ & \\
\hline $\mathrm{T} 4$ & 46 & $26(56.52)$ & & $4(8.70)$ & & $12(26.09)$ & \\
\hline Nerve invasion & & & 0.312 & & 0.693 & & 1.000 \\
\hline Yes & 3 & $3(100.00)$ & & $1(33.33)$ & & $1(33.33)$ & \\
\hline No & 57 & $30(52.63)$ & & $5(8.77)$ & & $15(26.32)$ & \\
\hline Vessel carcinoma embolus & & & $0.005^{\mathrm{b}}$ & & 1.000 & & 0.785 \\
\hline Yes & 32 & $23(71.87)$ & & $3(9.36)$ & & $9(28.13)$ & \\
\hline No & 28 & $10(35.71)$ & & $3(10.71)$ & & $7(25.00)$ & \\
\hline TNM stage & & & 0.077 & & 0.546 & & 0.755 \\
\hline I and II & 32 & $21(65.62)$ & & $2(6.25)$ & & $8(25.00)$ & \\
\hline III and IV & 28 & $12(42.86)$ & & $4(14.29)$ & & $8(28.57)$ & \\
\hline Lymph node metastasis & & & $0.020^{\mathrm{a}}$ & & 1.000 & & 0.559 \\
\hline Yes & 30 & $21(70.00)$ & & $3(10.00)$ & & $9(30.00)$ & \\
\hline No & 30 & $12(40.00)$ & & $3(10.00)$ & & $7(23.33)$ & \\
\hline Distant metastasis & & & 0.712 & & 1.000 & & 0.744 \\
\hline Yes & 11 & $5(45.45)$ & & $1(9.09)$ & & $2(18.18)$ & \\
\hline No & 49 & $28(57.14)$ & & $5(10.20)$ & & $14(28.57)$ & \\
\hline
\end{tabular}

${ }^{\mathrm{a}} \mathrm{P}<0.05,{ }^{\mathrm{b}} \mathrm{P}<0.01$. GEFT, guanine nucleotide exchange factor T; MMRD, mismatch repair protein-deficient; TNM, Tumor-Node-Metastasis; $2+/ 3+$, significantly increased positive expression.

TNM stage I/II samples, suggesting that GEFT may play an important role in the poor prognosis of these patients with GC. Therefore, the association between GEFT protein expression and OS was further analyzed. Although the survival rates of patients with GC with elevated GEFT expression was lower compared with patients with low GEFT expression, there was no significant association. However, increased sample sizes and longer follow-up time after surgery may be required to fully describe the association between GEFT and prognosis in patients with GC.

Numerous studies have implicated HER2 in the development of various types of cancer. HER 2 expression was detected in $6.1-23.0 \%$ of GCs cases (16-18). Similarly, the HER2-positive rate in the 60 GC samples in the present study was $13.33 \%$. However, the prognostic value of HER2 status in GC is still controversial. Some studies report that HER2 
Table VII. Expression of the four MMRPs in the colorectal cancer samples.

\begin{tabular}{lcccc}
\hline $\mathrm{n}$ & PMS2 & MSH2 & MSH6 & MLH1 \\
\hline 4 & - & + & + & + \\
1 & + & - & - & + \\
1 & - & + & + & - \\
54 & + & + & + & + \\
\hline
\end{tabular}

MMRP, mismatch repair protein.

Table VIII. MSI state in the colorectal cancer samples.

\begin{tabular}{lrccccc}
\hline MSI & $\mathrm{n}$ & Bat26 & Bat25 & D5S346 & D2S123 & D17S250 \\
\hline MSI-H & 3 & + & + & - & - & - \\
& 1 & + & + & + & - & - \\
& 1 & - & + & - & - & + \\
& 1 & - & + & - & + & - \\
MSI-L & 1 & - & + & - & - & - \\
MSS & 53 & - & - & - & - & - \\
\hline
\end{tabular}

MSI, microsatellite instability; $\mathrm{H}$, high; L, low; MSS, microsatellite stable.

Table IX. MSI results in CRC.

\begin{tabular}{lccc}
\hline Variable & MMR-D, $\mathrm{n}$ & MMR-I, & Total \\
\hline MSI-H & 5 & 1 & 6 \\
MSI-L & 1 & 0 & 1 \\
MSS & 0 & 53 & 53 \\
Total & 6 & 54 & 60
\end{tabular}

MSI, microsatellite instability; CRC, colorectal cancer; $\mathrm{H}$, high; L, low; MSS, microsatellite stable; MMR, mismatch repair protein; $\mathrm{D}$, deficient; I, intact.

overexpression is an adverse prognostic factor (41-44), but others suggest that there is no association between HER2 expression and survival rate (17,45-48). In the present study, HER2 protein expression was higher in tumors with nerve invasion, and significantly lower in TNM stage I/II samples compared with TNM stage III/IV samples. These findings corroborate another report showing that HER2 overexpression was associated with poor prognosis in patients with GC (44). Because both GEFT protein and HER2 upregulation was associated with GC TNM stage in the present study, further analysis of the correlation between GEFT and HER2 expression was performed. However, there was no significant correlation between these two proteins.

The high mortality rate of CRC, another common digestive tract tumor, stems from its metastatic potential (49). In the present study, GEFT protein expression levels were
Table X. KRAS mutations in colorectal cancer.

\begin{tabular}{lcccc}
\hline $\begin{array}{l}\text { Detected } \\
\text { region }\end{array}$ & Mutation & $\begin{array}{c}\text { Base } \\
\text { change }\end{array}$ & Incidence & $\begin{array}{c}\text { Mutation } \\
\text { rate }(\%)\end{array}$ \\
\hline Codon 12 & G12V & $35 \mathrm{G}>\mathrm{T}$ & 1 & 1.67 \\
& $\mathrm{G} 12 \mathrm{D}$ & $35 \mathrm{G}>\mathrm{A}$ & 10 & 13.33 \\
& $\mathrm{G} 12 \mathrm{R}$ & $34 \mathrm{G}>\mathrm{C}$ & 1 & 1.67 \\
& $\mathrm{G} 12 \mathrm{~S}$ & $34 \mathrm{G}>\mathrm{C}$ & 1 & 1.67 \\
Codon 13 & $\mathrm{G} 13 \mathrm{D}$ & $38 \mathrm{G}>\mathrm{A}$ & 3 & 5 \\
\hline
\end{tabular}

significantly higher in patients with CRC compared with the control samples. Furthermore, GEFT protein expression was higher in CRC samples with vessel carcinoma embolus or lymph node metastasis. These results suggested that the GEFT protein may promote CRC metastasis. The data in the present study demonstrate that the survival rates of patients with CRC with GEFT overexpression was lower compared with patients with lower GEFT expression. These patients also had a less favorable outcome compared with that of the low GEFT expression group. Therefore, GEFT may contribute to the poor prognosis of patients with $\mathrm{CRC}$ by promoting metastasis.

Several studies have reported that MSI is present in $\sim 15 \%$ of patients with CRC. The results of the present study showed that $10 \%$ of samples lost MMRP. Among the 60 CRC specimens, 6 were MSI-H, 1 was MSI-L and 53 were MSS. In comparison, the MSI rate in patients with CRC was $\sim 11.67 \%$. MSI status has been evaluated as a prognostic and predictive biomarker in patients with CRC. Specifically, patients diagnosed with CRC that are MSI-positive present with an improved prognosis when not treated with 5-florouracil chemotherapy following surgery (50). MSH CRCs are frequently located in the proximal colon (50-53), are poorly differentiated, and have mucinous or medullary histology. Additionally, MSH incidence is high in individuals $<50$ or $>70$ years old, but the incidence is low in patients between these ages (54). In the present study, the incidence of MMR-D was lower in patients with a maximal tumor diameter $\geq 5 \mathrm{~cm}$, but was not associated with any other clinicopathological parameters in patients with CRC. However, there was a significant inverse correlation between GEFT and MMRP expression. Therefore, it was speculated that MSH/L may be more common in patients with CRC with GEFT expression, though increased sample size and further experiments are required to validate this hypothesis.

KRAS is a small GTPase and a member of the RAS family. Activated KRAS promotes the regulation of cellular proliferation through the receptor tyrosine kinase MAPK/PI3K signaling cascades (55). The rate of KRAS gene mutations in CRC is $35-45 \%(28,56,57)$. In the present study, the rate of mutation was $26.67 \%$ in patients with CRC, which was notably lower than previously reported. Although KRAS gene mutation status in patients with CRC is used to inform treatment options, particularly in the selection of targeted therapeutic drugs such as cetuximab, the association between $K R A S$ gene mutations and the prognosis of patients with CRC has not been definitively determined. In the present study, the KRAS mutation rate was higher in poorly differentiated CRC compared 
with well/moderately differentiated tumors, although a difference in KRAS mutation status between other clinicopathologic features was not identified. This suggests that patients carrying tumors with KRAS mutations may exhibit shorter overall survival. Furthermore, a significant correlation between GEFT expression and KRAS mutation in CRC was identified. Notably, as both GEFT and KRAS proteins are small GTPases, both may be similarly involved in the development of CRC.

The systematic study described here demonstrated, for the first time, that the GEFT protein is expressed in malignant digestive tract tumors. The results indicate that GEFT protein expression is higher in ESCC, GC and CRC tumors compared with normal adjacent tissues. GEFT may predominantly act as a tumor promoter in adenocarcinomas of the stomach, as suggested by associations with diffuse tumor type and TNM stages III/IV in GC. In GC, HER2 was overexpressed and was associated with nerve invasion and TNM stages III/IV. Therefore, HER2 likely promoted the incidence of GC. Patients with CRC with upregulated protein expression of GEFT frequently had vessel carcinoma embolus or lymph node metastasis, and had a less favorable outcome. GEFT may contribute to poor prognosis of patients with CRC by promoting metastasis. The importance of MSI state and KRAS mutation status in patients with CRC was demonstrated. Furthermore, GEFT protein expression was associated with MSS and KRAS mutations. GEFT expression and $K R A S$ mutations, therefore, may synergistically promote the incidence of CRC.

In conclusion, GEFT may be an oncogenic factor in malignant digestive tract tumors, particularly in CRC. However, the specific underlying mechanisms involved in the progression of these tumors remain to be elucidated.

\section{Acknowledgements}

Not applicable.

\section{Funding}

The present study was supported by The Medical Technology Research and Development Program of Henan Province (Grant nos. 201701029 and 182102310343).

\section{Availability of data and materials}

The datasets used and/or analyzed during the present study are available from the author on reasonable request.

\section{Authors' contributions}

QX conceived and designed the experiments. YW performed the experiments, analyzed the data, and contributed to the writing of the manuscript. BG, GG and YZ contributed to the sample collection.

\section{Ethics approval and consent to participate}

The purpose of the present research was explained to the participants, who all signed a written consent prior to the study. The present study was approved by The Institutional Ethics
Committee of the Affiliated Cancer Hospital of Zhengzhou University (Zhengzhou, China).

\section{Patient consent for publication}

Not applicable.

\section{Competing interests}

The authors declare that they have no competing interests.

\section{References}

1. Bryan B, Kumar V, Stafford LJ, Cai Y, Wu G and Liu M: GEFT, a Rho family guanine nucleotide exchange factor, regulates neurite outgrowth and dendritic spine formation. J Biol Chem 279: 45824-45832, 2004.

2. Bryan BA, Mitchell DC, Zhao L, Ma W, Stafford LJ, Teng BB and Liu M: Modulation of muscle regeneration, myogenesis, and adipogenesis by the Rho family guanine nucleotide exchange factor GEFT. Mol Cell Biol 25: 11089-11101, 2005.

3. Guo X, Stafford LJ, Bryan B, Xia C, Ma W, Wu X, Liu D, Songyang Z and Liu M: A Rac/Cdc42-specific exchange factor, GEFT, induces cell proliferation, transformation, and migration. J Biol Chem 278: 13207-13215, 2003.

4. Paulson V, Chandler G, Rakheja D, Galindo RL, Wilson K, Amatruda JF and Cameron S: High-resolution array CGH identifies common mechanisms that drive embryonal rhabdomyosarcoma pathogenesis. Genes Chromosomes Cancer 50: 397-408, 2011.

5. Liu C, Li D, Hu J, Jiang J, Zhang W, Chen Y, Cui X, Qi Y, Zou H, Zhang W and Li F: Chromosomal and genetic imbalances in Chinese patients with rhabdomyosarcoma detected by high-resolution array comparative genomic hybridization. Int J Clin Exp Pathol 7: 690-698, 2014.

6. Sun C, Liu C, Li S, Li H, Wang Y, Xie Y, Li B, Cui X, Chen Y, Zhang W and Li F: Overexpression of GEFT, a Rho family guanine nucleotide exchange factor, predicts poor prognosis in patients with rhabdomyosarcoma. Int J Clin Exp Pathol 7: 1606-1615, 2014.

7. Lutz S, Freichel-Blomquist A, Rumenapp U,Schmidt M, Jakobs KH and Wieland T: p63RhoGEF and GEFT are Rho-specific guanine nucleotide exchange factors encoded by the same gene. Naunyn Schmiedebergs Arch Pharmacol 369: 540-546, 2004.

8. Tang X, Jin R, Qu G, Wang X, Li Z, Yuan Z, Zhao C, Siwko S, Shi T, Wang P, et al: GPR116, an adhesion G-protein-coupled receptor, promotes breast cancer metastasis via the Galphaqp63RhoGEF-Rho GTPase pathway. Cancer Res 73: 6206-6218, 2013.

9. Hayashi A, Hiatari R, Tsuji T, Ohashi K and Mizuno K: p63RhoGEF-mediated formation of a single polarized lamellipodium is required for chemotactic migration in breast carcinoma cells. FEBS Lett 587: 698-705, 2013.

10. Bryan BA, Cai Y and Liu M: The Rho-family guanine nucleotide exchange factor GEFT enhances retinoic acid- and cAMP-induced neurite outgrowth. J Neurosci Res 83: 1151-1159, 2006.

11. Siegel RL, Miller KD and Jemal A: Cancer statistics, 2018. CA Cancer J Clin 68: 7-30, 2018.

12. Sjoquist KM, Burmeister BH, Smithers BM, Zalcberg JR, Simes RJ, Barbour A and Gebski V; Australasian Gastro-Intestinal Trials Group: Survival after neoadjuvant chemotherapy or chemoradiotherapy for resectable oesophageal carcinoma: An updated meta-analysis. Lancet Oncol 12: 681-692, 2011.

13. Pennathur A, Gibson MK, Jobe BA and Luketich JD: Oesophageal carcinoma. Lancet 381: 400-412, 2013.

14. Hadi AA, Hindawi AE, Hareedy A, Khalil H, Ashiry RA, Elia S, Sadek A, Magdy M, Atta R, Anas A, et al: Her2/neu protein expression and oncogene amplification in gastric carcinoma with clinico-pathological correlation in egyptian patients. Open Access Maced J Med Sci 4: 535-542, 2016.

15. Moore MA, Eser S, Igisinov N, Igisinov S, Mohagheghi MA, Mousavi-Jarrahi A, Ozentürk G, Soipova M, Tuncer M and Sobue T: Cancer epidemiology and control in North-Western and Central Asia-past, present and future. Asian Pac J Cancer Prev 11 (Suppl 2): S17-S32, 2010. 
16. Hsu JT, Chen TC, Tseng JH, Chiu CT, Liu KH, Yeh CN, Hwang TL, Jan YY and Yeh TS: Impact of HER-2 overexpression/amplification on the prognosis of gastric cancer patients undergoing resection: A single-center study of 1,036 patients. Oncologist 16: 1706-1713, 2011.

17. Sheng WQ, Huang D, Ying JM, Lu N, Wu HM, Liu YH, Liu JP, $\mathrm{Bu} \mathrm{H}$, Zhou XY and Du X: HER2 status in gastric cancers: A retrospective analysis from four Chinese representative clinical centers and assessment of its prognostic significance. Ann Oncol 24: 2360-2364, 2013.

18. Bang YJ, Van Cutsem E, Feyereislova A, Chung HC, Shen L, Sawaki A, Lordick F, Ohtsu A, Omuro Y, Satoh T, et al: Trastuzumab in combination with chemotherapy versus chemotherapy alone for treatment of HER2-positive advanced gastric or gastro-oesophageal junction cancer (ToGA): A phase 3, open-label, randomised controlled trial. Lancet 376: 687-697, 2010.

19. Ferlay J, Soerjomataram I, Dikshit R, Eser S, Mathers C, Rebelo M, Parkin DM, Forman D and Bray F: Cancer incidence and mortality worldwide: Sources, methods and major patterns in GLOBOCAN 2012. Int J Cancer 136: E359-E386, 2015.

20. Kriegl L: In situ analyses of molecular mechanisms of colorectal carcinogenesis. Pathologe 34 (Suppl 2): S269-S273, 2013 (In German)

21. Zhang $X$ and Li J: Era of universal testing of microsatellite instability in colorectal cancer. World J Gastrointest Oncol 5: 12-19, 2013.

22. Boland CR and Goel A: Microsatellite instability in colorectal cancer. Gastroenterology 138: 2073-2087.e3, 2010.

23. Yamamoto $\mathrm{H}$ and Imai $\mathrm{K}$ : Microsatellite instability: An update Arch Toxicol 89: 899-921, 2015.

24. Peltomäki $\mathrm{P}$, Lothe RA, Aaltonen LA, Pylkkänen L, Nyström-Lahti M, Seruca R, David L, Holm R, Ryberg D, Haugen A, et al: Microsatellite instability is associated with tumors that characterize the hereditary non-polyposis colorectal carcinoma syndrome. Cancer Res 53: 5853-5855, 1993.

25. Herman JG, Umar A, Polyak K, Graff JR, Ahuja N, Issa JP, Markowitz S, Willson JK, Hamilton SR, Kinzler KW, et al: Incidence and functional consequences of hMLH1 promoter hypermethylation in colorectal carcinoma. Proc Natl Acad Sci USA 95: 6870-6875, 1998.

26. Hampel H, Frankel WL, Martin E, Arnold M, Khanduja K, KueblerP, Clendenning M, Sotamaa K, Prior T, Westman JA, et al: Feasibility of screening for Lynch syndrome among patients with colorectal cancer. J Clin Oncol 26: 5783-5788, 2008.

27. Vaughn CP, Zobell SD, Furtado LV, Baker CL and Samowitz WS Frequency of KRAS, BRAF, and NRAS mutations in colorectal cancer. Genes Chromosomes Cancer 50: 307-312, 2011.

28. Amado RG, Wolf M, Peeters M, Van Cutsem E, Siena S, Freeman DJ, Juan T, Sikorski R, Suggs S, Radinsky R, et al: Wild-type KRAS is required for panitumumab efficacy in patients with metastatic colorectal cancer. J Clin Oncol 26 1626-1634, 2008.

29. Lièvre A, Bachet JB, Le Corre D, Boige V, Landi B, Emile JF, Côté JF, Tomasic G, Penna C, Ducreux M, et al: KRAS mutation status is predictive of response to cetuximab therapy in colorectal cancer. Cancer Res 66: 3992-3995, 2006.

30. Sorich MJ, Wiese MD, Rowland A, Kichenadasse G, McKinnon RA and Karapetis CS: Extended RAS mutations and anti-EGFR monoclonal antibody survival benefit in metastatic colorectal cancer: A meta-analysis of randomized, controlled trials. Ann Oncol 26: 13-21, 2015.

31. Edge SB and Compton CC: The American Joint Committee on Cancer: The 7th edition of the AJCC cancer staging manual and the future of TNM. Ann Surg Oncol 17: 1471-1474, 2010

32. Hofmann M, Stoss O, Shi D, Büttner R, van de Vijver M, Kim W, Ochiai A, Rüschoff J and Henkel T: Assessment of a HER2 scoring system for gastric cancer: Results from a validation study. Histopathology 52: 797-805, 2008.

33. Boland CR, Thibodeau SN, Hamilton SR, Sidransky D, Eshleman JR, Burt RW, Meltzer SJ, Rodriguez-Bigas MA, Fodde R, Ranzani GN and Srivastava S: A National Cancer Institute Workshop on Microsatellite Instability for cancer detection and familial predisposition: Development of international criteria for the determination of microsatellite instability in colorectal cancer. Cancer Res 58: 5248-5257, 1998.

34. Fukata M, Nakagawa M and Kaibuchi K: Roles of Rho-family GTPases in cell polarisation and directional migration. Curr Opin Cell Biol 15: 590-597, 2003.

35. Sahai E and Marshall CJ: RHO-GTPases and cancer. Nat Rev Cancer 2: 133-142, 2002.
36. Stiekema J, Cats A, Kuijpers A, van Coevorden F, Boot $\mathrm{H}$, Jansen EP, Verheij M, Balague Ponz O, Hauptmann M and van Sandick JW: Surgical treatment results of intestinal and diffuse type gastric cancer. Implications for a differentiated therapeutic approach? Eur J Surg Oncol 39: 686-693, 2013.

37. Chen YC, Fang WL, Wang RF, Liu CA, Yang MH, Lo SS, Wu CW, Li AF, Shyr YM and Huang KH: Clinicopathological variation of lauren classification in gastric cancer. Pathol Oncol Res 22: 197-202, 2016

38. Tanner M, Hollmén M, Junttila TT, Kapanen AI, Tommola S, Soini Y, Helin H, Salo J, Joensuu H, Sihvo E, et al: Amplification of HER-2 in gastric carcinoma: Association with Topoisomerase IIalpha gene amplification, intestinal type, poor prognosis and sensitivity to trastuzumab. Ann Oncol 16: 273-278, 2005.

39. Yamashita K, Sakuramoto S, Katada N, Futawatari N, Moriya H, Hirai K, Kikuchi S and Watanabe M: Diffuse type advanced gastric cancer showing dismal prognosis is characterized by deeper invasion and emerging peritoneal cancer cell: The latest comparative study to intestinal advanced gastric cancer. Hepatogastroenterology 56: 276-281, 2009.

40. Zheng H, Takahashi H, Murai Y, Cui Z, Nomoto K, Miwa S, Tsuneyama K and Takano Y: Pathobiological characteristics of intestinal and diffuse-type gastric carcinoma in Japan: An immunostaining study on the tissue microarray. J Clin Pathol 60: 273-277, 2007.

41. Gravalos $\mathrm{C}$ and Jimeno A: HER2 in gastric cancer: A new prognostic factor and a novel therapeutic target. Ann Oncol 19: 1523-1529, 2008.

42. Liang JW, Zhang JJ, Zhang T and Zheng ZC: Clinicopathological and prognostic significance of HER2 overexpression in gastric cancer: A meta-analysis of the literature. Tumour Biol 35: 4849-4858, 2014.

43. Dang HZ, Yu Y and Jiao SC: Prognosis of HER2 over-expressing gastric cancer patients with liver metastasis. World J Gastroenterol 18: 2402-2407, 2012

44. Lei YY, Huang JY, Zhao QR, Jiang N, Xu HM, Wang ZN, Li HQ, Zhang SB and Sun Z: The clinicopathological parameters and prognostic significance of HER2 expression in gastric cancer patients: A meta-analysis of literature. World J Surg Oncol 15: 68, 2017.

45. Janjigian YY, Werner D, Pauligk C, Steinmetz K, Kelsen DP, Jäger E, Altmannsberger HM, Robinson E, Tafe LJ, Tang LH, et al: Prognosis of metastatic gastric and gastroesophageal junction cancer by HER2 status: A European and USA International collaborative analysis. Ann Oncol 23: 2656-2662, 2012.

46. Kunz PL, Mojtahed A, Fisher GA, Ford JM, Chang DT, Balise RR, Bangs CD, Cherry AM and Pai RK: HER2 expression in gastric and gastroesophageal junction adenocarcinoma in a US population: Clinicopathologic analysis with proposed approach to HER2 assessment. Appl Immunohistochem Mol Morphol 20: 13-24, 2012.

47. Grabsch H, Sivakumar S, Gray S, Gabbert HE and Muller W: HER2 expression in gastric cancer: Rare, heterogeneous and of no prognostic value-conclusions from 924 cases of two independent series. Cell Oncol 32: 57-65, 2010

48. Qiu M, Zhou Y, Zhang X, Wang Z, Wang F, Shao J, Lu J, Jin Y, Wei X, Zhang D, et al: Lauren classification combined with HER2 status is a better prognostic factor in Chinese gastric cancer patients. BMC Cancer 14: 823, 2014

49. Elferink MA, de Jong KP, Klaase JM, Siemerink EJ and de Wilt JH: Metachronous metastases from colorectal cancer: A population-based study in North-East Netherlands. Int J Colorectal Dis 30: 205-212, 2015.

50. Gryfe R, Kim H, Hsieh ET, Aronson MD, Holowaty EJ, Bull SB, Redston $\mathrm{M}$ and Gallinger S: Tumor microsatellite instability and clinical outcome in young patients with colorectal cancer. $\mathrm{N}$ Engl J Med 342: 69-77, 2000.

51. Jeong SY, Shin KH, Shin JH, Ku JL, Shin YK, Park SY, Kim WH and Park JG: Microsatellite instability and mutations in DNA mismatch repair genes in sporadic colorectal cancers. Dis Colon Rectum 46: 1069-1077, 2003.

52. Thibodeau SN, Bren G and Schaid D: Microsatellite instability in cancer of the proximal colon. Science 260: 816-819, 1993 .

53. Bertagnolli MM, Redston M, Compton CC, Niedzwiecki D, Mayer RJ, Goldberg RM, Colacchio TA, Saltz LB and Warren RS: Microsatelliteinstability and loss of heterozygosity at chromosomal location 18q: Prospective evaluation of biomarkers for stages II and III colon cancer-a study of CALGB 9581 and 89803. J Clin Oncol 29: 3153-3162, 2011. 
54. Samowitz WS, Curtin K, Ma KN, Schaffer D, Coleman LW, Leppert $M$ and Slattery ML: Microsatellite instability in sporadic colon cancer is associated with an improved prognosis at the population level. Cancer Epidemiol Biomarkers Prev 10: 917-923, 2001.

55. Ahearn IM, Haigis K, Bar-Sagi D and Philips MR: Regulating the regulator: Post-translational modification of RAS. Nat Rev Mol Cell Biol 13: 39-51, 2011.

56. Karapetis CS, Khambata-Ford S, Jonker DJ, O'Callaghan CJ, Tu D, Tebbutt NC, Simes RJ, Chalchal H, Shapiro JD, Robitaille S, et al: K-ras mutations and benefit from cetuximab in advanced colorectal cancer. N Engl J Med 359: 1757-1765, 2008.
57. Peeters M, Price TJ, Cervantes A, Sobrero AF, Ducreux M, Hotko Y, André T, Chan E, Lordick F, Punt CJ, et al: Randomized phase III study of panitumumab with fluorouracil, leucovorin, and irinotecan (FOLFIRI) compared with FOLFIRI alone as second-line treatment in patients with metastatic colorectal cancer. J Clin Oncol 28: 4706-4713, 2010 